Suffering Scholars 
INTELLECTUAL HISTORY OF THE MODERN AGE

Series Editors

Angus Burgin

Peter E. Gordon

Joel Isaac

Karuna Mantena

Samuel Moyn

Jennifer Ratner-Rosenhagen

Camille Robcis

Sophia Rosenfeld 


\section{Suffering Scholars}

Pathologies of the Intellectual in Enlightenment France

\section{Anne C. Vila}

\section{$\overline{\text { PENN }}$}

UNIVERSITY OF PENNSYLVANIA PRESS

PHILADELPHIA 
Copyright (C) 2018 University of Pennsylvania Press

All rights reserved. Except for brief quotations used for purposes of review or scholarly citation, none of this book may be reproduced in any form by any means without written permission from the publisher.

Published by

University of Pennsylvania Press

Philadelphia, Pennsylvania 191041-4112

www.upenn.edu/pennpress

Printed in the United States of America on acid-free paper

10988765543321

Library of Congress Cataloging-in-Publication Data

ISBN 978-0-8122-4992-7 